\title{
DESIGN OF HOT MIX ASPHALT USING BAILEY METHOD OF GRADATION
}

\author{
Manjunath K.R ${ }^{1}$, Poornachandra Dev N.B ${ }^{2}$ \\ ${ }^{1}$ Assistant Professor, Department of Civil Engineering, DSCE, Bangalore, India \\ ${ }^{2}$ Student, M.Tech, Highway Technology, DSCE, Bangalore, India
}

\begin{abstract}
This study investigates the properties of Hot Mix Asphalt (HMA) mixtures designed using Bailey method of gradation and compared with conventional method of gradation. Bailey method is a systematic approach in blending aggregates that provides aggregate interlocking as backbone of the structure and develop strong aggregate skeleton for rut resistance and durability. The Bailey method allows the designer to select an aggregate skeleton that will be more resistant to permanent deformation and to adjust the VMA (voids in mineral aggregate) by changing packing of coarse aggregate and fine aggregate with sufficient asphalt binder. Two hot mix mixtures considered in this study are Bituminous concrete (BC) grade 1 and grade 2. The mixtures have nominal maximum particle size (NMPS) of $19 \mathrm{~mm}$ and $13 \mathrm{~mm}$. The aggregate structure designed using Bailey method are applied in Marshall method of mix design to obtain Marshall properties according to Indian standards and gradation parameters were compared with requirement of MORTH specifications. The tests for determining volumetric properties and Indirect Tensile Strength of mix are conducted and compared with aggregate structure designed using conventional method of gradation. Further the rutting characteristics of both gradations are modelled using Rolling Compactor cum Rut Analyser (RCRA) equipment for different field temperatures.
\end{abstract}

Keywords: Aggregate structure, Rutting, Stability, Voids. $* * *$

\section{INTRODUCTION}

Hot mix asphalt (HMA) is the most common material used for paving applications in India. It primarily consists of asphalt binder and mineral aggregates. HMA is the composite material consisting of aggregate particle with different sizes, an asphalt binder and air voids. When mineral aggregates are bound with asphalt binder, it acts as stone framework that provides strength and toughness to the system. [1]

Several mixture design have been developed over time to achieve proper desired properties like durability, permeability, strength, stability, fatigue and stiffness. However other control points that affect the properties of asphalt mixture is gradation of aggregates. A strong aggregate structure is required in mix because aggregates support most of the compressive forces delivered on it.

The Bailey Method is based on how the coarse and fine aggregates pack together to form a strong aggregate skeleton. The Bailey Method was developed by Robert Bailey, a retired materials engineer for the Illinois Department of Transportation. The method develops a strategy to create a strong aggregate skeleton for rut resistance, durability, and adequate voids in the mineral aggregate. A strong aggregate structure is important because the aggregate supports most of the compressive forces. [13]

Use of the Bailey method will ensure coarse aggregate interlock and control of aggregate packing, allowing the designer to specify desired mixture properties. This will eliminate the normal trial and error process used in determining the design aggregate gradations and will help in the transition to contractor mix design. The evaluation tools in the Bailey method can also be used for quality control during the construction process. The proper changes to the production process can be made to meet the quality requirements in the field as a result of the understanding of the effects of aggregate gradations on the properties of the asphalt mixture. [2]

The Bailey method of gradation evaluation focus on the aggregate properties that affect the way aggregates fit together (or pack) in a confined space or volume. To analyse the packing factors, the method defines four key principles that break down the overall combined aggregate blend into four distinct fractions. Each fraction is then analysed for its contribution to the overall mix volumetric. [12]

\subsection{Objectives}

The objectives of present research work are

1) Primary objective of the proposed study is to design aggregate gradation based on Bailey method of gradation and achieve required volumetric properties and necessary compressive characteristics over conventional method of gradation.

2) To determine the optimum bitumen content required for the improved method of gradation.

3) To determine Indirect Tensile Strength of the bituminous mixture designed using Conventional method and Bailey method of gradation. 
4) To determine rutting characteristics of the mixture using Rolling Compactor cum Rut Analyser (RCRA) equipment and develop a better rut resistant asphalt mixture using Bailey method of gradation.

\section{LITERATURE REVIEW}

HMA is the most popular bituminous mix. It primarily consists of asphalt cement binder and mineral aggregates. The binder acts as an adhesive agent that binds aggregate particles into a cohesive mass. When bound by asphalt cement binder, mineral aggregate acts as a stone framework that provided strength and toughness to the system. The behaviour of HMA depends on the properties of the individual components and how they react with each other in the system. [4]

Aggregates are the one of the principal material in HMA. They play an important role in the performance of asphalt mixtures. For HMA, they make up about 90 to 95 percent by weight and comprise 75 to 85 percent of the volume. [3][10]

Elliot et al., conducted an investigation to evaluate the effect of different aggregate gradations on the properties of asphalt mixtures. The aggregate blends included: coarse, fine, and medium gradations and two poorly graded. From this investigation, they concluded that:

$>$ Variations in gradation have the greatest effect when the general shape of the gradation curve is changed (i.e., coarse-to-fine \& fine-to-coarse gradations).

$>$ Fine gradation produced the highest Marshall stability, while the fine-to-coarse poorly graded gradation (with hump at sand sized) produced the lowest Marshall stability. [5]

Kandhal et al., studied the effect of aggregate gradation on measured asphalt content. A total of 547 binder coarse mix samples and 147 wearing coarse mix samples were obtained from field projects and the asphalt cement was extracted using ASTM D2172 "Standard Test Methods for Quantitative Extraction of Bitumen from Bituminous Paving Mixtures" procedure. Correlation analysis was performed to determine if the pavement layer density or the percentage passing various sieve sizes correlate with asphalt cement content. It was concluded that for binder course mixtures, the percent passing the $4.75 \mathrm{~mm}$ and $2.36 \mathrm{~mm}$ sieves correlated with measured asphalt cement content. Prediction equations were developed to adjust the measured asphalt cement content to account for the change in gradation from the job mix formula on the $12.5 \mathrm{~mm}$ sieve and either 4.75 $\mathrm{mm}$ or $2.36 \mathrm{~mm}$ sieves. [6]

Krutz et al., evaluated the effects of aggregate gradation on permanent deformation of HMA mixtures for the Nevada Department of Transportation. They utilized four different gradations, two aggregate sources, and two sources of asphalt cement AC20 asphalt cement. Two of the gradations were labelled as extreme fine and extreme coarse with $60 \%$ and $43 \%$ passing sieve No. 4 , respectively. The middle gradations had $52 \%$ and $54 \%$ passing sieve No. 4. The Hveem mixture design method was followed to design the asphalt mixtures. Repeated load triaxial test was used to evaluate all the mixtures. The key findings of this research were that the best aggregate gradations is dependent on the type and source of aggregate and that coarse aggregate gradations performed the worst and fine aggregate. [8]

Sousa et al., studied the effect of gradation on the fatigue life of asphalt mixtures using the SHRP-M009 four-point bending fatigue test. Above restricted zone (ARZ), through restricted zone (TRZ) and below restricted zone (BRZ) gradations ranging in NMS from 12.5 to $25.0 \mathrm{~mm}$ were evaluated. Six aggregate sources and two PG binder grades were used to produce nine mixtures. Four gradations were designed above the restricted zone (fine), three through the restricted zone (medium) and two below the restricted zone (coarse). All aggregates were $100 \%$ crushed granite. The coarse mixtures were designed using the Superpave mix design method $\left(\mathrm{N}_{\mathrm{des}}=143\right.$ gyrations $)$. Five of the nine mixtures were designed using the Marshall method, one using a roller wheel compactor, and one using the Quebec mixture design method. Fatigue test specimens were prepared using a lightweight steel roller compactor with a target air void level of $7 \%$. All tests were performed at $20^{\circ} \mathrm{C}$ in strain control mode. Fatigue life was defined as the number of load cycles required to reduce the initial mixture stiffness $50 \%$. Key findings presented from the study were that fine graded mixtures exhibited better fatigue performance than mixtures with coarse gradations and the worst fatigue performance was exhibited by one of the Superpave mixtures. [11]

Kandhal et al., conducted a study with the objective of evaluating the effect of mixture gradation on rutting potential of dense graded mixtures. The performance of eighteen mixtures was evaluated based on the results from the Asphalt Pavement Analyzer (APA) and Superpave Shear Tester (SST) tests. Two mixture types (12.5 and $19.0 \mathrm{~mm})$, three aggregate types (granite, limestone, and partially crushed gravel), and three gradation types (ARZ, TRZ, and BRZ) were considered. The coarse fraction of the gradation curve $(+4.75 \mathrm{~mm})$ was held constant while the fine portion of the gradation was adjusted to produce the different gradation blends. A PG 64-22 binder was used and mixtures were designed in accordance with the Superpave mix design method with $\mathrm{N}_{\text {des }}=76$ gyrations corresponding to traffic level of 0.3 to 1.0 million ESAL. Both APA and SST performance test specimens were compacted to four percent air voids with the Superpave Gyratory Compactor (SGC). APA tests were conducted at $64^{\circ} \mathrm{C}$ and Repeated Shear at Constant height (RSCH) tests was conducted in accordance with AASHTO TP7. Analysis of APA rut depths indicated that aggregate type, gradation, and NMPS, as well as interaction between aggregate type and gradation were significant. Significant difference between rut depths of ARZ, TRZ, and BRZ mixtures was observed. Considering all data, mixes with gravel and limestone aggregates generally show higher rutting than granite. Also, for granite and limestone, mixes with gradation below restricted zone 
generally showed highest amount of rutting, whereas gradations through restricted zone generally showed the lowest rut depth. The above restricted zone generally showed intermediate rutting. The RSCH test results did not appear to be as sensitive to differences in gradations as the ones obtained from the APA test. [7]

\section{METHODOLOGY}

The purpose of this study was to evaluate the laboratory performance of asphalt mixtures with aggregate gradations that were designed using Bailey method. Two different types of gradation were selected in this study and tests were carried out according to the IS specifications.

The coarse aggregates used are crushed hard rock passing $20 \mathrm{~mm}, 12 \mathrm{~mm}$ and $6 \mathrm{~mm}$ sieve sizes. The quarry dust passing $2.36 \mathrm{~mm}$ sieve is used as mineral filler. Various tests conducted to determine basic properties of aggregates are given in Table 3.1. A VG-30 (60/70 grade) bitumen is used in the present study. The tests conducted to determine the basic properties of bitumen are shown Table 3.2.

Table -3.1: Physical properties of coarse aggregates

\begin{tabular}{|l|l|l|l|l|}
\hline $\begin{array}{l}\text { SI. } \\
\text { No. }\end{array}$ & Properties & $\begin{array}{l}\text { Test } \\
\text { method }\end{array}$ & $\begin{array}{l}\text { Obtained } \\
\text { values }\end{array}$ & $\begin{array}{l}\text { IS } \\
\text { specifications }\end{array}$ \\
\hline 1 & $\begin{array}{l}\text { Crushing } \\
\text { value }\end{array}$ & $\begin{array}{l}\text { IS-2386 } \\
\text { part IV }\end{array}$ & $25.1 \%$ & Max 30\% \\
\hline 2 & $\begin{array}{l}\text { Abrasion } \\
\text { value }\end{array}$ & $\begin{array}{l}\text { IS-2386 } \\
\text { part IV }\end{array}$ & $34.38 \%$ & Max 30\% \\
\hline 3 & Impact value & $\begin{array}{l}\text { IS-2386 } \\
\text { part IV }\end{array}$ & $23.9 \%$ & Max 24\% \\
\hline 4 & $\begin{array}{l}\text { Combined } \\
\text { Elokingation } \\
\text { index }\end{array}$ & $\begin{array}{l}\text { IS-2386 } \\
\text { part I }\end{array}$ & $21.56 \%$ & Max 30\% \\
\hline 5 & $\begin{array}{l}\text { Water } \\
\text { test }\end{array}$ & $\begin{array}{l}\text { IS-2386 } \\
\text { part III }\end{array}$ & $0.25 \%$ & Max 2\% \\
\hline
\end{tabular}

Aggregate gradation greatly influences the performance of the pavement layers. Mixture design was performed on all the aggregate structures that were formulated using the Bailey method and conventional method of aggregate gradation. For the design purpose wearing course layer,

Table - 3.2: Physical properties of Bitumen.

\begin{tabular}{|l|l|l|l|l|}
\hline $\begin{array}{l}\text { SI. } \\
\text { No. }\end{array}$ & Properties & $\begin{array}{l}\text { Test } \\
\text { method }\end{array}$ & $\begin{array}{l}\text { Obtained } \\
\text { values }\end{array}$ & $\begin{array}{l}\text { Specifications } \\
\text { as per IS:73 }\end{array}$ \\
\hline 1 & $\begin{array}{l}\text { Penetration, } \\
(\mathrm{mm}) \\
\left(100 \mathrm{~g}, 25^{\circ} \mathrm{C},\right. \\
5 \mathrm{sec})\end{array}$ & $\begin{array}{l}\text { IS: } \\
1203- \\
1978\end{array}$ & 65 & $60-70$ \\
\hline 2 & $\begin{array}{l}\text { Softening } \\
\text { point }\left({ }^{\circ} \mathrm{C}\right)\end{array}$ & $\begin{array}{l}\text { IS: } \\
1205- \\
1978\end{array}$ & 52.4 & $45-55$ \\
\hline 3 & $\begin{array}{l}\text { Ductility at } \\
27^{\circ} \mathrm{C}(\mathrm{mm})\end{array}$ & $\begin{array}{l}\text { IS: } \\
1208- \\
1978\end{array}$ & 100 & Min 75 \\
\hline 4 & $\begin{array}{l}\text { Specific } \\
\text { gravity }\end{array}$ & $\begin{array}{l}\text { IS: } \\
1202- \\
1978\end{array}$ & 1.01 & Min 0.99 \\
\hline 5 & $\begin{array}{l}\text { Flash point } \\
\text { test }\left({ }^{\circ} \mathrm{C}\right)\end{array}$ & $\begin{array}{l}\text { IS: } \\
1209- \\
1978\end{array}$ & 280 & Min 175 \\
\hline 6 & $\begin{array}{l}\text { Fire point } \\
\text { test }\left({ }^{\circ} \mathrm{C}\right)\end{array}$ & $\begin{array}{l}\text { IS: } \\
1209 \\
1978\end{array}$ & 315 & Min 175 \\
\hline
\end{tabular}

Bituminous Concrete (BC) of Grade 1 and Grade 2 are selected. Table 3.3 shows the combined obtained gradation for BC Grade-1 designed using Trial and Error procedure. Table 3.4 shows the combined obtained gradation for $\mathrm{BC}$ Grade-2 designed using Trial and Error procedure.

Table -3.3: Combined obtained gradation from Trial and Error method for BC Grade-1

\begin{tabular}{|c|c|c|c|c|c|c|}
\hline \multirow{2}{*}{$\begin{array}{l}\text { Sieve } \\
\text { Size }\end{array}$} & $20 \mathrm{~mm}$ & $12 \mathrm{~mm}$ & $6 \mathrm{~mm}$ & Dust & \multirow{2}{*}{$\begin{array}{l}\text { Obtained } \\
\text { Gradation }\end{array}$} & \multirow{2}{*}{$\begin{array}{l}\text { Specified } \\
\text { limits }\end{array}$} \\
\hline & $39 \%$ & $17 \%$ & $20 \%$ & $24 \%$ & & \\
\hline 26.5 & 100 & 100 & 100 & 100 & 100.0 & 100 \\
\hline 19 & 100 & 100 & 100 & 100 & 100.0 & $79-100$ \\
\hline 13.2 & 41.2 & 99.9 & 100 & 100 & 77.1 & $59-79$ \\
\hline 9.5 & 17.1 & 92.7 & 99.8 & 100 & 66.4 & $52-72$ \\
\hline 4.75 & 9.5 & 38.3 & 67.25 & 100 & 47.7 & $35-55$ \\
\hline 2.36 & 0 & 23.7 & 7.9 & 99.4 & 29.5 & $28-44$ \\
\hline 1.18 & 0 & 16.1 & 1.2 & 95 & 25.8 & $20-34$ \\
\hline 0.6 & 0 & 11.3 & 0.7 & 81 & 21.5 & $15-27$ \\
\hline 0.3 & 0 & 7.8 & 0.55 & 63 & 16.6 & $10-20$ \\
\hline 0.15 & 0 & 4.25 & 0.4 & 45.5 & 11.7 & $5-13$ \\
\hline 0.075 & 0 & 1.2 & 0.25 & 20 & 5.1 & $2-8$ \\
\hline
\end{tabular}




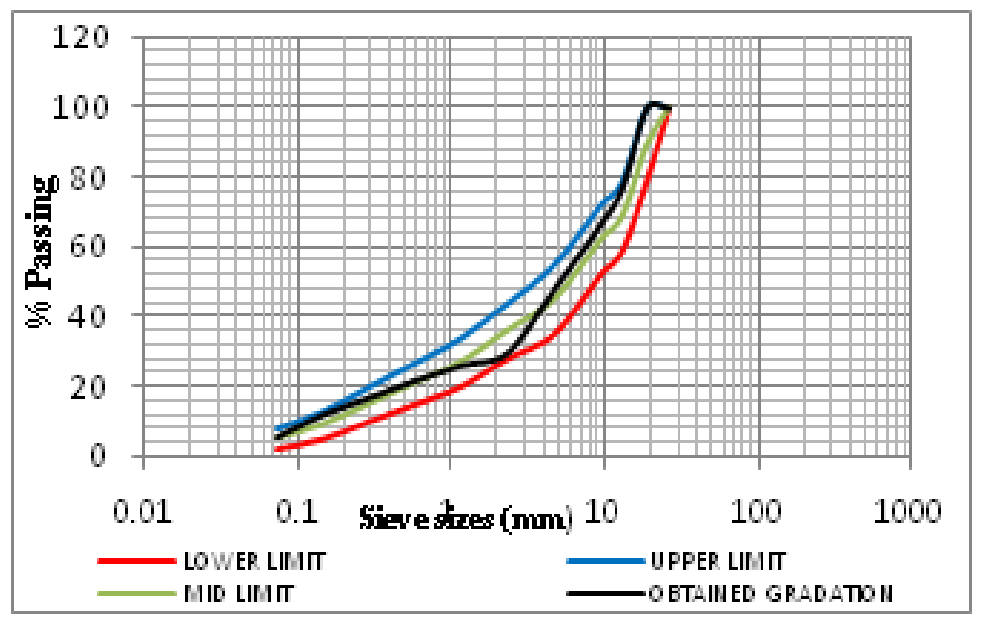

Fig -3.1: Obtained gradation from Trial and Error method for BC Grade-1

Table -3.4: Combined obtained gradation from Trial and Error method for BC Grade-2

\begin{tabular}{|l|l|l|l|l|l|l|}
\hline \multirow{2}{*}{$\begin{array}{l}\text { sieve } \\
\text { size }\end{array}$} & $20 \mathrm{~mm}$ & $12 \mathrm{~mm}$ & $6 \mathrm{~mm}$ & Dust & $\begin{array}{l}\text { Obtained } \\
\text { Gradation }\end{array}$ & $\begin{array}{l}\text { Specified } \\
\text { limits }\end{array}$ \\
\cline { 2 - 6 } 19 & $21 \%$ & $12 \%$ & $27.0 \%$ & $40 \%$ & 100.0 & 100 \\
13.2 & 41.2 & 99.9 & 100 & 100 & 87.6 & $79-100$ \\
9.5 & 17.1 & 92.7 & 99.8 & 100 & 81.7 & $70-88$ \\
4.75 & 9.5 & 38.3 & 67.25 & 100 & 64.7 & $53-71$ \\
2.36 & 0 & 23.7 & 7.9 & 99.4 & 44.7 & $42-58$ \\
1.18 & 0 & 16.1 & 1.2 & 95 & 40.3 & $34-48$ \\
0.6 & 0 & 11.3 & 0.7 & 81 & 33.9 & $26-38$ \\
0.3 & 0 & 7.8 & 0.55 & 63 & 26.3 & $18-28$ \\
0.15 & 0 & 4.25 & 0.4 & 45.5 & 18.8 & $12-20$ \\
0.075 & 0 & 1.2 & 0.25 & 20 & 8.2 & $4-10$ \\
\hline
\end{tabular}

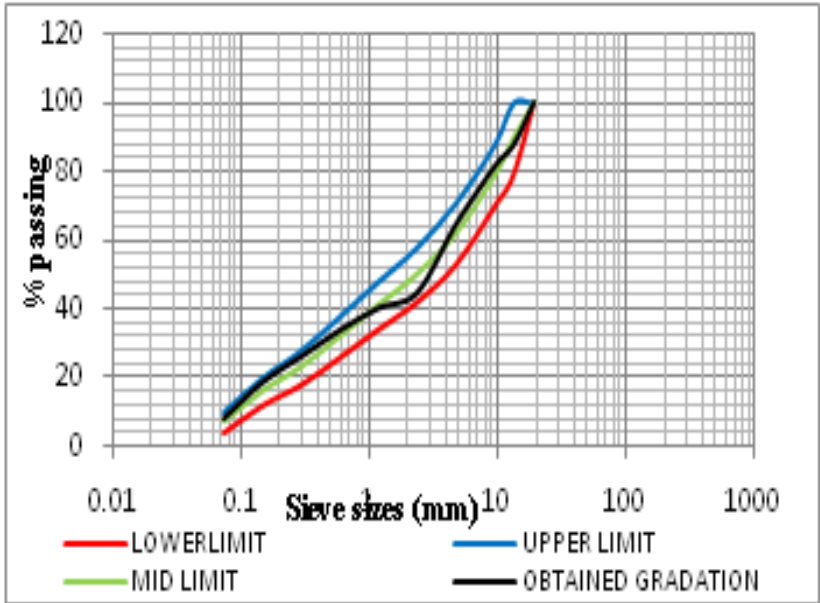

Fig -3.2: Obtained gradation from Trial and Error method for BC Grade-2

In Bailey's method of gradation, aggregates are first combined to determine the amount and size of voids created by coarse aggregates and appropriate amount of fine aggregate to fill those voids. To determine void structure required to evaluate interlock, loose and rodded unit weights of coarse aggregate must be determined. Also, for fine aggregates rodded unit weight must be determined. The combined gradation obtained from Bailey method of gradation, designed for Bituminous Concrete (BC) of Grade1 and Grade-2 are shown in Table -3.5 and table -3.6 .

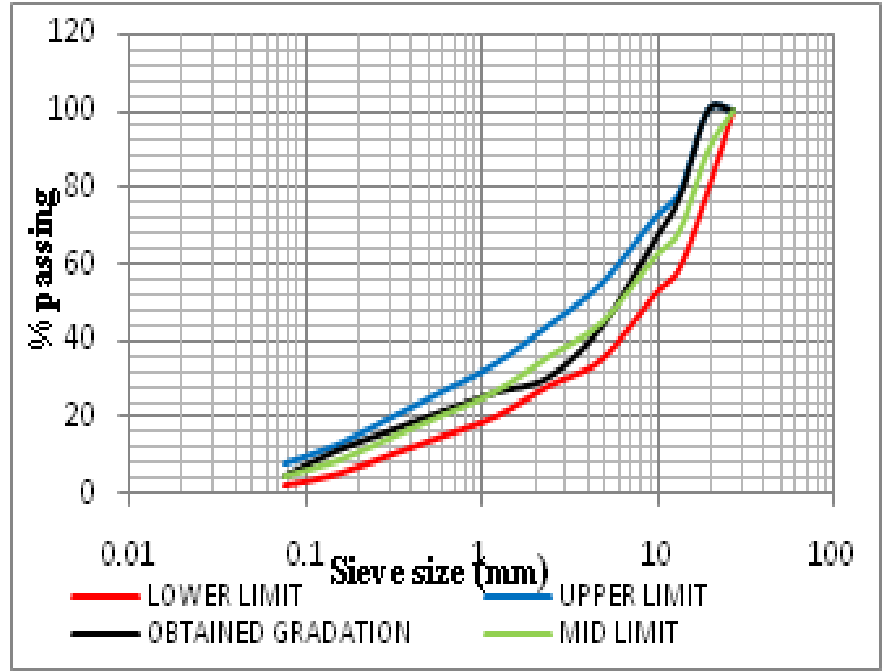

Fig -3.3: Obtained gradation from Bailey method for BC Grade-1 
Table -3.5: Combined obtained gradation from Bailey method for BC Grade-1

\begin{tabular}{|l|l|l|l|l|l|l|}
\hline Sieve Size & $\begin{array}{l}\text { CA\#A } \\
20 \mathrm{~mm}\end{array}$ & $\begin{array}{l}\text { CA\#B } \\
12 \mathrm{~mm}\end{array}$ & $\begin{array}{l}\text { FA\#C } \\
6 \mathrm{~mm}\end{array}$ & Dust & $\begin{array}{l}\text { Obtained } \\
\text { Gradation }\end{array}$ & $\begin{array}{l}\text { Specified } \\
\text { limits }\end{array}$ \\
\cline { 1 - 5 } Design \% & $37.9 \%$ & $31.0 \%$ & $8.4 \%$ & $22.8 \%$ & 100 & 100 \\
26.5 & 100 & 100 & 100 & 100 & 100 & $79-100$ \\
19 & 100 & 100 & 100 & 100 & 100.00 & $59-79$ \\
9.5 & 41.2 & 99.9 & 100 & 100 & 77.68 & $52-72$ \\
4.75 & 17.1 & 92.7 & 99.8 & 100 & 66.30 & $35-55$ \\
2.36 & 9.5 & 38.3 & 67.25 & 100 & 43.85 & $28-44$ \\
1.18 & 0 & 23.7 & 7.9 & 99.4 & 30.62 & $20-34$ \\
0.6 & 0 & 16.1 & 1.2 & 95 & 26.70 & $15-27$ \\
0.3 & 0 & 11.3 & 0.7 & 81 & 21.99 & $10-20$ \\
0.15 & 0 & 7.8 & 0.55 & 63 & 16.80 & $5-13$ \\
0.075 & 0 & 4.25 & 0.4 & 45.5 & 11.70 & $2-8$ \\
\hline$G_{\text {sb }}$ & 0 & 1.2 & 0.25 & 20 & 4.94 & \\
LUW $^{*}$ & 2.65 & 2.68 & 2.7 & 2.808 & & Design unit \\
RUW $* *$ & 1354 & 1378 & NA & NA & weight & \\
\hline
\end{tabular}

*LUW - Loose unit weight $\left(\mathrm{Kg} / \mathrm{m}^{3}\right)$.

**RUW - Rodded unit weight $\left(\mathrm{Kg} / \mathrm{m}^{3}\right)$.

Table -3.6: Combined obtained gradation from Bailey method for BC Grade-2

\begin{tabular}{|l|l|l|l|l|l|l|}
\hline Sieve Size & $\begin{array}{l}\text { CA\#A } \\
20 \mathrm{~mm}\end{array}$ & $\begin{array}{l}\text { CA\#B } \\
12 \mathrm{~mm}\end{array}$ & $\begin{array}{l}\text { FA\#C } \\
6 \mathrm{~mm}\end{array}$ & Dust & $\begin{array}{l}\text { Obtained } \\
\text { Gradation }\end{array}$ & $\begin{array}{l}\text { Specified } \\
\text { limits }\end{array}$ \\
\hline Design \% & $21.0 \%$ & $20.6 \%$ & $20.4 \%$ & $38 \%$ & & 100 \\
19 & 100 & 100 & 100 & 100 & 100.00 & $79-100$ \\
9.5 & 41.2 & 99.9 & 100 & 100 & 87.63 & $70-88$ \\
4.75 & 17.1 & 92.7 & 99.8 & 100 & 81.04 & $53-71$ \\
2.36 & 9.5 & 38.3 & 67.25 & 100 & 61.61 & $42-58$ \\
1.18 & 0 & 23.7 & 7.9 & 99.4 & 44.30 & $34-48$ \\
0.6 & 0 & 16.1 & 1.2 & 95 & 39.69 & $26-38$ \\
0.3 & 0 & 11.3 & 0.7 & 81 & 33.28 & $18-28$ \\
0.15 & 0 & 7.8 & 0.55 & 63 & 25.68 & $12-20$ \\
0.075 & 0 & 4.25 & 0.4 & 45.5 & 18.26 & $4-10$ \\
\hline Gsb & 0 & 1.2 & 0.25 & 20 & 7.90 & $105 \%$ \\
LUW* & 2.65 & 2.68 & 2.7 & 2.808 & & \\
RUW ** & 1354 & 1378 & NA & NA & Design & unit \\
\hline
\end{tabular}

*LUW - Loose unit weight. **RUW - Rodded unit weight

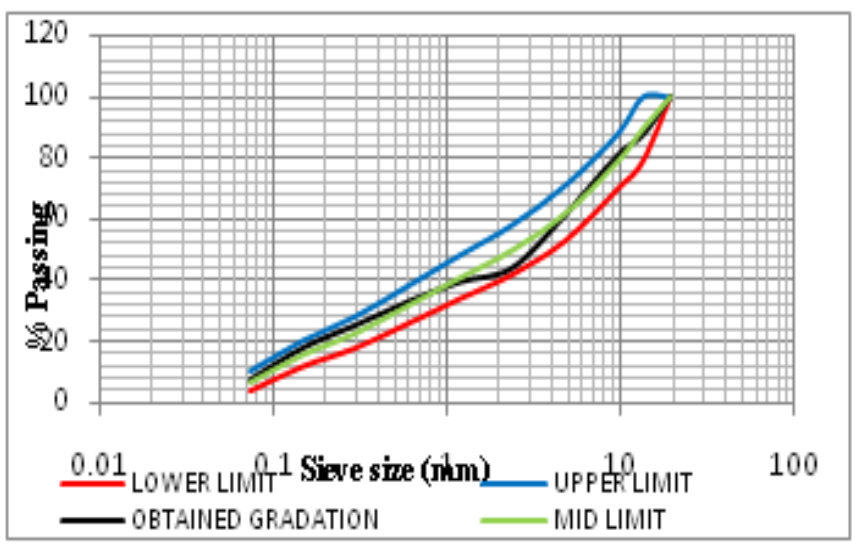

\subsection{Marshall Mix Design}

The Marshall Stability tests were conducted with varying bitumen content to find volumetric properties and optimum bitumen content of the bituminous mixes designed using conventional and Bailey methods. The results are tabulated in Table -3.7

Fig -3.4: Obtained gradation from Bailey method for BC Grade-2 
Table -3.7: Marshall stability test results

\begin{tabular}{|l|l|l|l|l|l|}
\hline \multirow{2}{*}{$\begin{array}{l}\text { SI. } \\
\text { No }\end{array}$} & \multirow{2}{*}{$\begin{array}{l}\text { Propertie } \\
\text { s }\end{array}$} & $\begin{array}{l}\text { BC Grade-1 } \\
\text { Trial } \\
\text { and } \\
\text { Error }\end{array}$ & $\begin{array}{l}\text { Baile } \\
\text { y }\end{array}$ & $\begin{array}{l}\text { Trial } \\
\text { and } \\
\text { Error }\end{array}$ & $\begin{array}{l}\text { Baile } \\
\text { binder } \\
\text { content in } \\
(\%)\end{array}$ \\
\hline 2 & $\begin{array}{l}\text { Stability } \\
\text { (Kg) }\end{array}$ & 9.79 & 5.75 & 5.96 & 6.17 \\
\hline 3 & $\begin{array}{l}\text { Flow } \\
\text { (mm) }\end{array}$ & 4.7 & 970 & 1040 & 1060 \\
\hline 4 & $\begin{array}{l}\text { Bulk } \\
\text { density } \\
\text { (gm/cc) }\end{array}$ & 2.34 & 2.34 & 2.37 & 2.35 \\
\hline 5 & $\begin{array}{l}\text { Volume of } \\
\text { air voids } \\
\text { in (\%) }\end{array}$ & 4.2 & 4 & 3.2 & 3.4 \\
\hline 6 & VMA (\%) & 9 & 9.5 & 9.5 & 9 \\
\hline 7 & VFB (\%) & 56 & 57 & 64 & 63 \\
\hline
\end{tabular}

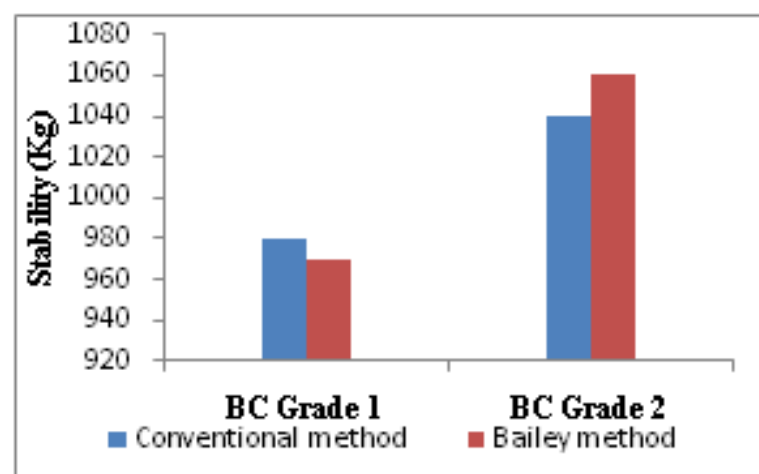

Fig -3.5: Relation between Stability and aggregate structure designed using various gradations

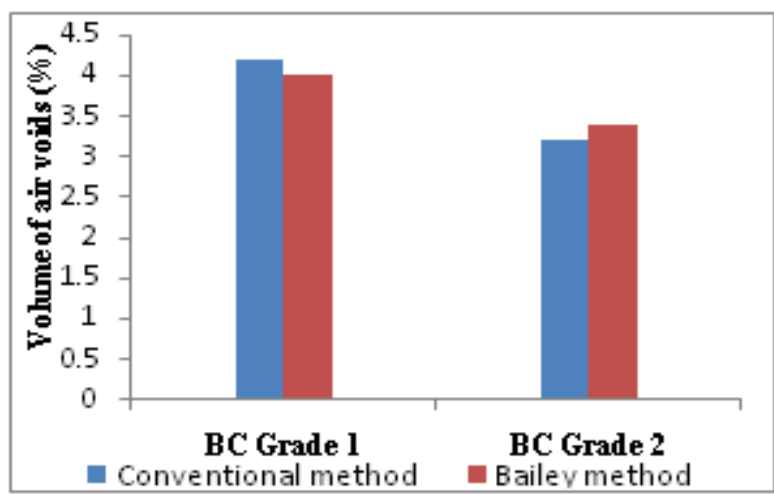

Fig -3.6: Relation between Volume of air voids and aggregate structure designed using various gradations.

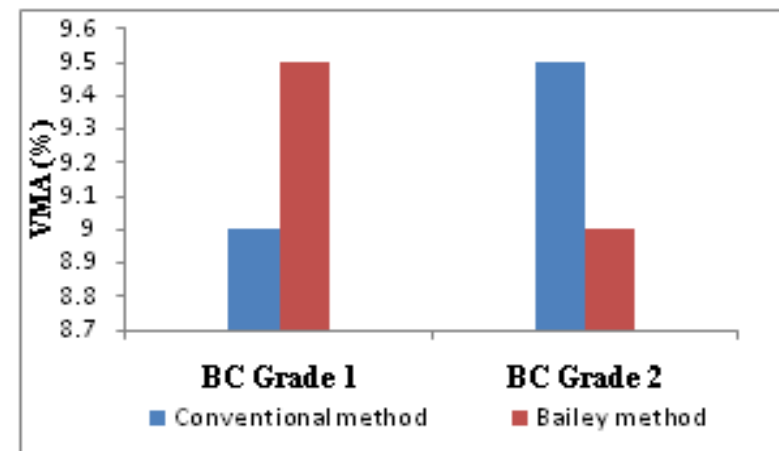

Fig -3.7: Relation between Voids in Mineral Aggregates (VMA) and aggregate structure designed using various gradations.

\subsection{Indirect Tensile Strength Test (ITS)}

The indirect tensile strength test was conducted on unconditioned specimens casted at $\mathrm{OBC}$. The specimens were soaked in water bath at $25 \pm 1^{\circ} \mathrm{C}$ for 2 hours and tested for load at failure. The results of indirect tensile strength test performed on $\mathrm{BC}$ mix are presented below.

Table -3.8: Results of Indirect tensile strength test.

\begin{tabular}{|l|l|l|}
\hline \multirow{2}{*}{ Gradation type } & \multicolumn{2}{|l|}{$\begin{array}{l}\text { Indirect } \\
\text { strength (N/mm2) }\end{array}$} \\
\cline { 2 - 3 } & $\begin{array}{l}\text { BC } \\
\text { Grade-1 }\end{array}$ & $\begin{array}{l}\text { BC } \\
\text { Grade-2 }\end{array}$ \\
\hline $\begin{array}{l}\text { Conventional } \\
\text { method }\end{array}$ & 0.36 & 0.33 \\
\hline Bailey method & 0.39 & 0.37 \\
\hline
\end{tabular}

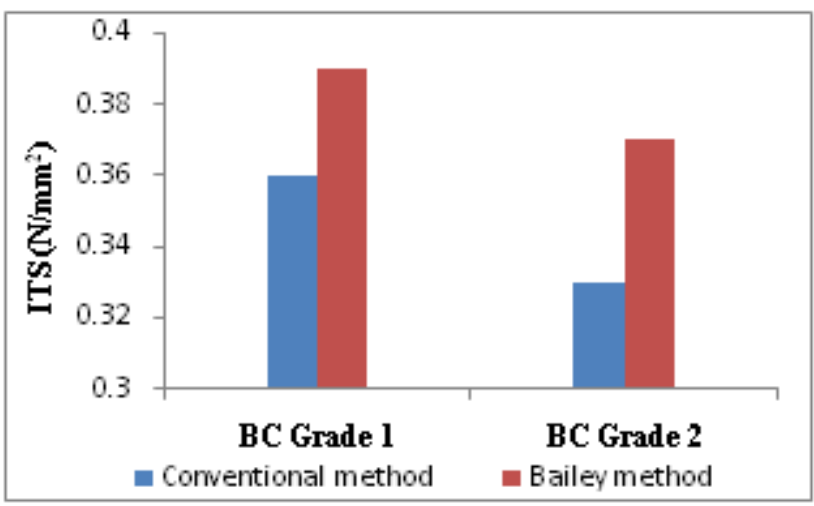

Fig -3.8: Variation of Indirect tensile strength with gradation.

\subsection{Rutting Characteristics}

The Bituminous concrete (BC) specimens of Grade 1 and Grade 2 and height $65 \mathrm{~mm}$ and $45 \mathrm{~mm}$ respectively were casted at $\mathrm{OBC}$ and analysed for rut depth of $12 \mathrm{~mm}$ at a tyre pressure of $8.4 \mathrm{Kg} / \mathrm{cm}^{2}$ and various rutting temperatures $\left(30^{\circ} \mathrm{C}\right.$ and $\left.60^{\circ} \mathrm{C}\right)$. 
Table -3.9: Number of passes for various rutting temperatures for rut depth of $12 \mathrm{~mm}$ for different gradations

\begin{tabular}{|l|l|l|l|l|}
\hline \multirow{2}{*}{$\begin{array}{l}\text { Temperature } \\
\left({ }^{\circ} \mathbf{C}\right)\end{array}$} & \multicolumn{3}{|l|}{ Number of passes } \\
\cline { 2 - 5 } & $\begin{array}{l}\text { BC Grade-1 } \\
\text { Trial } \\
\text { and } \\
\text { Error }\end{array}$ & Bailey & $\begin{array}{l}\text { Trial } \\
\text { and } \\
\text { Error }\end{array}$ & Bailey \\
\hline 30 & 10200 & 13300 & 9700 & 10300 \\
\hline 60 & 3100 & 3800 & 2800 & 3200 \\
\hline
\end{tabular}

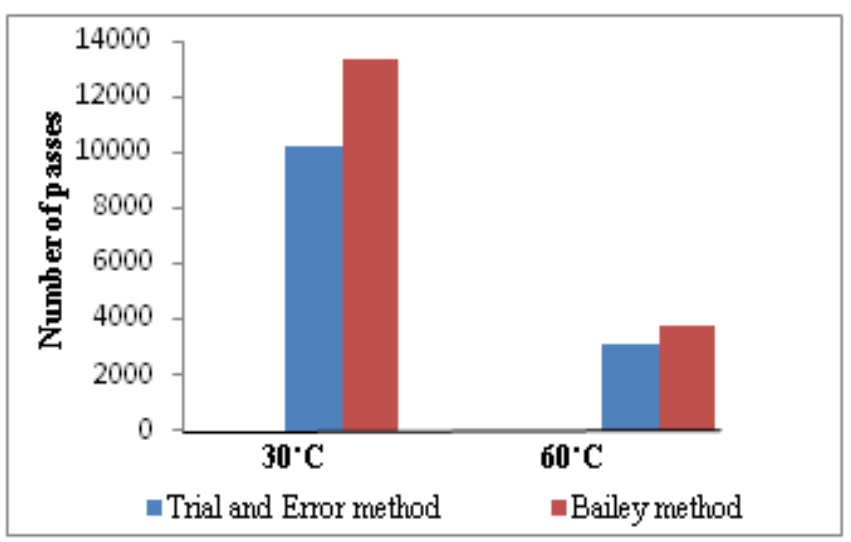

Fig -3.9: Relationship between number of passes at varying rutting temperatures for BC Grade 1.

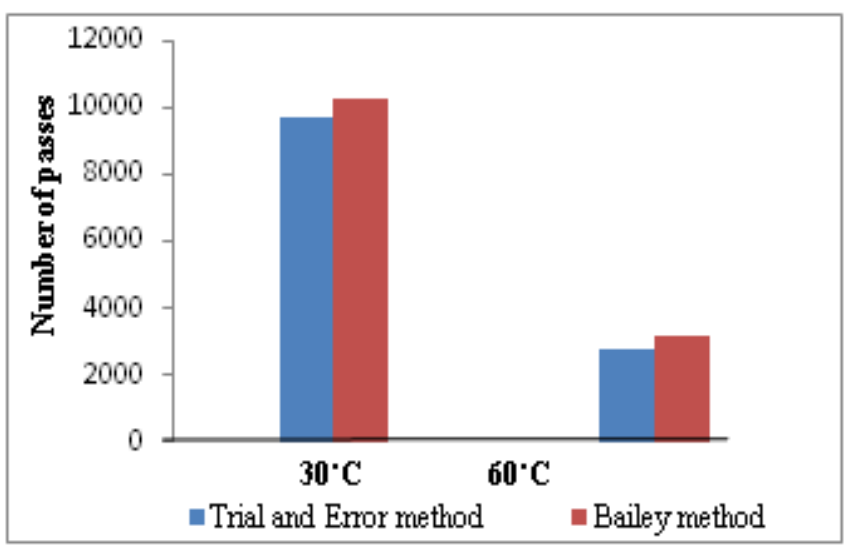

Fig -3.10: Relationship between number of passes at varying rutting temperatures for BC Grade 2.

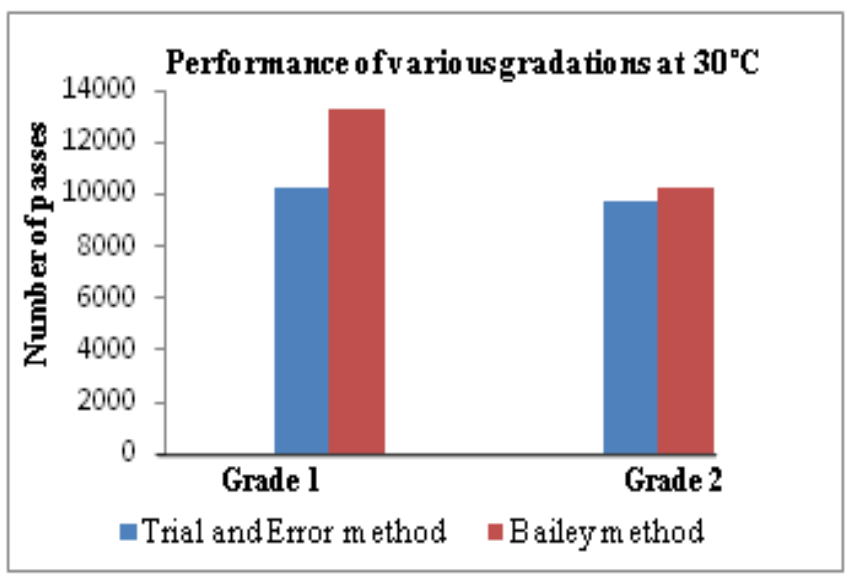

Fig -3.11: Relationship between number of passes and temperature at $30^{\circ} \mathrm{C}$ for different gradations

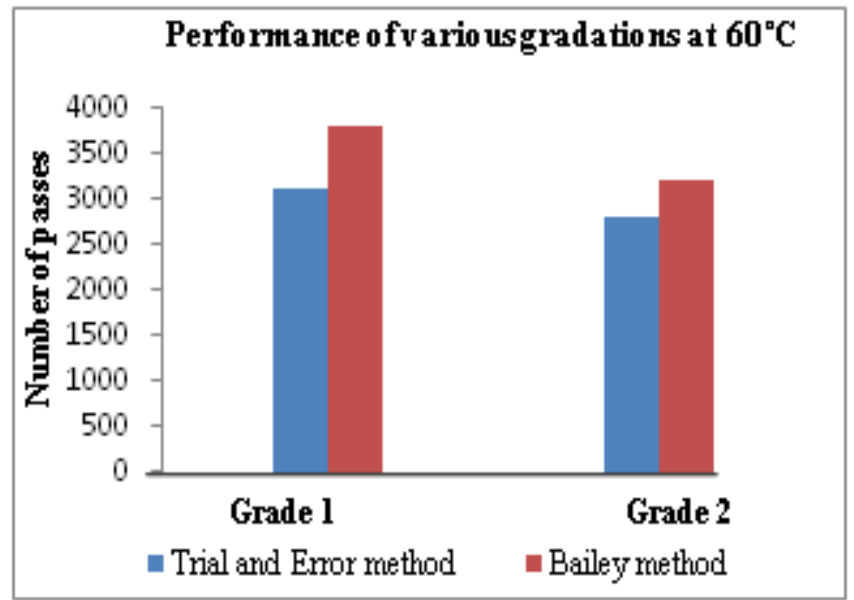

Fig -3.12: Relationship between number of passes and temperature at $60^{\circ} \mathrm{C}$ for different gradations.

\section{CONCLUSIONS}

$>\quad$ The aggregate gradation obtained using Bailey method is almost in line with the mid limits specified by the MoRT\&H standards.

$>$ Even though the Marshall stability of both the methods doesn't vary much, the Bailey method predicted an increase in VMA for all the mixtures in this study. But there was a significant decrease in VMA as the mix gets finer.

$>\quad$ The indirect tensile strength value of unconditioned specimens has an increment of $8.33 \%$ for $\mathrm{BC}$ Grade- 1 and $12.12 \%$ for BC Grade-2 with Bailey method of gradation.

$>$ The relation between number of passes and rut depth at $30^{\circ} \mathrm{C}$ and tyre pressure of $8.4 \mathrm{Kg} / \mathrm{cm}^{2}$ was obtained for both the method of gradations. The rut depth observed with BC Grade-1 after 10200 passes was $12 \mathrm{~mm}$ for Conventional method. The rut depth reduces to $9.03 \mathrm{~mm}(75.25 \%)$ for Bailey method of gradation. The rut depth observed with BC Grade-2 after 9700 passes was $12 \mathrm{~mm}$ for Conventional method. The rut depth reduces to $9.82 \mathrm{~mm}(81.83 \%)$ for Bailey method of gradation.

$>\quad$ As the rutting temperature increases to $60^{\circ} \mathrm{C}$, the rut depth observed with BC Grade-1 after 3100 passes was $12 \mathrm{~mm}$ for Conventional method of gradation. The rut depth reduces to $9.33 \mathrm{~mm}(77.75 \%)$ for Bailey method gradation. The rut depth observed with BC Grade-2 after 2800 passes was $12 \mathrm{~mm}$ for Conventional method of gradation. The rut depth reduces to $10.4 \mathrm{~mm}(86.67 \%)$ for Bailey method of gradation.

$>$ The number of passes required for BC Grade-1 bituminous mix at $30^{\circ} \mathrm{C}$ is increased by $30 \%$ with Bailey method of gradation and it is increased by $6.2 \%$ for BC Grade-2 mix.

$>$ At $60^{\circ} \mathrm{C}$ even though the performance of bituminous mix against rutting decreases, Bailey method of gradation showed a better performance than Conventional method of gradation. 


\section{REFERENCES}

[1] Alshamsi, K. (2006). "Development of a Mix Design Methodology for Asphalt Mixtures with Analytically Formulated Aggregate Structures". Journal of Association of Asphalt Paving Technology.

[2] Aurilio, V., William, J. P. and Lum. P (2005). "The Bailey Method Achieving Volumetric and HMA Compatibility", Course Materials and Hand outs.

[3] Asphalt Institute (2001). "HMA Construction: Marshall Method". Manual Series No. 22 (MS-22). Lexington, KY.

[4] Baladi, G. Y., Lyles R. W. and Harichandran. R. S, (1998), "Asphalt Mix Design: An Innovative Approach". The 67th Annual Meeting of the Transportation Research Board, National Research Council, Washington, D. C., January 11-14.

[5] Elliot, R. P., M. C. Ford, M. Ghanim, and Y. F. Tu. "Effect of Aggregate Gradation Variation on Asphalt Concrete Mix Properties". In Transportation Research Record 1317, TRB, National Research Council, Washington, DC, 1991.

[6] Kandhal, P. S; Cross, S. A. "Effect of Aggregate Gradation on Measured Asphalt Content", NCAT Report No. 93-1, April 1993.

[7] Kandhal, P.S., and R. B. Mallick., " Effect of Mix Gradation on Rutting Potential of Dense Graded Asphalt Mixtures", 80th annual meeting of the Transportation research Board, Washington, D. C., August 2000.

[8] Krutz, N. C., and P. E. Sebaaly. "The Effects of Aggregate Gradation on Permanent Deformation of Asphalt Concrete". In Proceedings, Vol. 62, Association of Asphalt Paving Technologists, 1993.

[9] MoRTH "Specifications for Roads and Bridge Works"- 2004, Fifth revision, Indian Roads Congress, New Delhi.

[10] Roberts, F. L., Kandhal, P. S., Brown, E. R., Lee, D. Y., and Kennedy, T. W., (1996). "Hot Mix Asphalt Materials, Mixture Design and Construction". (2nd ed.) NAPA Research and education Foundation: Lanham, Maryland.

[11] Sousa, J. B.; J. C. Pais; M. Prates; P. Langlois; and A. M. Leclerc. "Effect of Aggregate Gradation on Fatigue Life of Asphalt Concrete Mixtures", A paper presentation at the 77th Annual Meeting of the Transportation Research Board, Washington, D. C., January, 1998.

[12] Vavrik, WR; Pine, WJ; Huber, G; Carpenter, SH; Bailey, R. "The Bailey Method of Gradation Evaluation: The Influence of Aggregate Gradation and Packing Characteristics on Voids in the Mineral Aggregate". Journal of the Association of Asphalt paving Technology, Volume 70, 2001.

[13] Vavrik, W. R., Huber, G. A., Pine, W. J., Carpenter, S. H., and Bailey, R., (2002). "Bailey Method for Gradation Selection in HMA Mixture Design". Transportation Research Circular E-C044. Bailey Method for Gradation Selection in Hot-Mix Asphalt Mixture Design, TRB, National Research Council, Washington, D.C. 